\title{
Action Research: A Practice to Improve Academic Performance among Undergraduate Psychology Students at the South African University Campus
}

\author{
Jabulani G. Kheswa \\ Department of Psychology, University of Fort Hare, Private Bag X 1314, Alice, 5700 South Africa \\ Email:jkheswa@ufh.ac.za
}

\section{Doi:10.5901/mjss.2014.v5n27p1043}

\begin{abstract}
In determining how best to improve learner-centeredness and academic performance of Psychology students at the University of Fort Hare (UFH), an Action Research (AR) was employed. Research indicates that overcrowding, lack of resource, poor command of English and poverty- stricken background impact adversely on the academic performance of most black South African students at tertiary institutions. The study was underpinned by Vygotsky's theory which advocates scaffolding and ZPD for successful teaching and learning. The sample size consisted of 26 convenient undergraduate students in the Foundation or Extended Programme class, whose informed consent, integrity and privacy were safeguarded. In group form, students cited that collaboration and interaction with the lecturers could equip them with more knowledge and insight as they contribute to their self-esteem. Given this findings, the recommendations are: (1) Lecturers should introduce various forms of teaching such as participatory approach and (2) Educational resources be available for students to access computer centres.
\end{abstract}

Keywords: action research, collaboration, learner-centeredness,

\section{Introduction}

Kurt Lewin, the main pioneer of action research, viewed action research and practice as interwoven and emerged out of the assumption that a theory can be expressed in action (Field \& Leicester, 2003). Action research engages lecturers and students into critical reflection, democratic practices, enlightenment and emancipation (Walker, 1993). In classroom situation, lecturers do not merely observe something happening; they become actively involved in ensuring that it brings about a positive change (Gummesson, 2000). According to Wilkerson and Irby (1998), for such changes to materialize, lecturers must therefore acquire new knowledge, skills and ability to deal with more small groups, more problem - based tutorials and new computer- based instructional programs.

Action research solves a problem and contributes to the body of knowledge (i.e. theory) and is interactive. Both the lecturers and students should cooperate continuously to gather new information in order to improve their system. It develops holistic understanding. As universities are dynamic socio- technical systems, lecturers need to have a broad view of how the system works, hence change and transformation are inevitable. There should be acquisition of new knowledge and skills for sustainability and growth. Furthermore, it encourages harmonious relationship between the lecturers and students, which is based on norms and values as enshrined in the constitution of the university (Gummesson, 2000). For example, anti-discriminatory policies and actions which may be influenced by gender, culture, sexual orientation, religion, marital status and disability should be refrained from, as advocated by the Constitution of the Republic of South Africa, Act no. 106 of 1998.

\section{The Scholarship of Teaching}

"There can be no improvement in learning and teaching when scholarship of teaching is not developed" (Menger, Weiner \& Associates, 1996)

The scholarship of teaching refers to the knowledge of literature (i.e. discipline) or subject matter by lecturers and transforming it meaningfully so that students, in turn, become critical thinkers (Trigwell, Martin, Benjamin \& Prosser, 2000). According to Kreber (2000), scholarship of teaching entails three different knowledge- domains, namely; instructional knowledge (i.e. knowledge acquisition of the course by lecturers), pedagogical knowledge (i.e. knowledge that lecturers have about how students learn), and curricular knowledge (i.e. teaching objectives and the purpose or future prospects of the course). Furthermore, according to Antonio, Astin and Cress (2000), to strengthen scholarship of 
teaching, lecturers must ensure that research is on-going (i.e. scholarship of discovery), disciplines are linked (i.e. scholarship of integration) and connections are developed (scholarship of application).

In addition, Wilkerson and Irby (1998), suggest that lecturers should go beyond course- mastery: they should translate the content to students by involving them into activities which require self- discovery. In that way, one may be in the position to say that learning has taken place because there is an observable change in behaviour (e.g. reasoning ability in writing assignments and during discussions). Drawing from Pratt and Associates' (1994) work, which emphasizes transmission and developmental perspectives, as a lecturer, I must make efficient use of lecture time by engaging students in discussions through probing them in order to verify their conceptualization of content. Once I have made diagnostic assessment, I should attempt to summarize for them the important areas without making learning teacher-centred. Swartz, de la Rey, Townsend, Duncan and O'Neil (2011) state that when positive communication prevails during lectures, students become intrinsically motivated and may develop the desire to study on their own with little supervision from their lecturer, who may act as a scaffold (temporary supporter), according to Vygotsky's sociocultural theory. Socio- cultural theory asserts that learning become meaningful when it takes place in the zone of proximal development (ZPD) of the learner, whereby learners are transmitted cultural values and beliefs, and encouraged to be socially responsible and active participants in the acquisition of knowledge.

\section{Problem Statement}

In South Africa, majority of first year students at tertiary institutions are faced with enormous challenges ranging from course selection, adaptation, to poor academic performance (Scott, 2009). The constant failure and the accompanying feelings of incompetence could be discouraging and demoralizing, resulting in them skip classes and drop out of the university prematurely (Bee \& Boyd, 2003) and with multicultural and multilingual student body especially in historically black universities such as the University of Zululand, inability to converse in English contribute immensely to the students' poor academic performance as English is not their mother-tongue (Boughey, 2000). A sharp contrast is brought by Bozalek and Biersteker (2010) who found that the historically resourced institutions such as the Stellenbosch University (SUN) in Cape Province, South Africa, where the medium of instruction is still predominantly White and conducting lectures in Afrikaans, students complete their degrees at the record time as compared to coloureds and IsiXhosaspeaking black students from poverty -stricken communities (e.g. Cape Flats, Langa, Khayelitsha) attending at the University of Western Cape (UWC). For language deficit, Nel and Muller (2010) found that learners who grow up without an exposure to television, lacking opportunities to read or speak English from an early age, inaccessibility to newspapers and magazines and taught by educators whose English proficiency is limited, tend to perform poorly academically. Black students constitute the majority of higher education drop-outs (Scott, 2009), in a quantitative study conducted by Letseka and Breier (2008) on the academic preparedness at South African universities, it was found that only $15 \%$ of black students managed to complete their degrees in the designated time, 30\% dropped out after the first year and further 20\% dropped out after their second and third year. Also, failure rate was attributable to lecturers who do not involve students in teaching and learning. Mudau (2004) stresses that inflexible curriculum tend to contribute towards barriers to learning because some students expect lecturers to work at a slower pace. According to Department of Education (2002) it becomes worse for students with poor command of English as they may fail to acquire skills in literacy, numeracy and in the management of their own learning.

In my Psychology classes (e.g. first years) students are overcrowded and characterized by diversity and barriers to learning (e.g. overcrowding, language barriers, and inadequate resources such as textbooks and data- projectors in the lecture halls). However, to reach to all students, I rely on blackboard as a form of teaching, whereby students get their notes electronically and that seems to facilitate learning. The advantage is that students could also prepare in advance, and communicate with me by dropping me in the inbox areas that need to be clarified without waiting for the lecture(r). According to the Curriculum and Assessment Policy Statement (CAPS) for IT (De Jager, 2011), universities must have up-to-date computer technology (e.g. data projector, software, anti-virus protection and access to internet) in order to equip learners with necessary skills. However, in historically black universities, Nonyane and Mlitwa (2008) found that provision of infrastructure, equipment and finances for computers is not yet made and students are expected to master computers and submit assignments electronically.

Against this background, the researcher sought to answer the following questions: What role is played by the lecturer in improving the academic performance of students in Psychology? To what extent are group discussions effective during lectures? How can group discussions improve English usage in academic discourse? 


\section{Aims and Objectives of the Research}

The research aims are as follows:

$\checkmark$ To determine the role played by the lecturer in improving the academic performance of students in Psychology.

$\checkmark$ To determine the effectiveness of group discussion during lectures

$\checkmark$ To improve English usage in academic discourse through group discussions.

\section{Theoretical Framework}

A theoretical framework is defined as a statement of the assumptions brought to the research task and reflected in the methodology as we understand and employ it. It thus serves as the basis of the method used to answer the research question (Leedy \& Ormrod, 2005). This research study is guided by the theory of Vygotsky.

\section{Research Methodology}

Action research can include all types of data gathering methods. Qualitative and quantitative tools such as interviews and surveys are used. It requires a breadth of pre- understanding of the environment, condition of the classrooms, the structure and dynamics of operating systems. Pre- understanding refers to the knowledge the action researcher brings to the research project. In other words, lecturers must know the factors which might be contributing towards unpreparedness and lack of participation by students during lesson. It should be conducted in real time. The problem should be solved as it unfolds and it should be "live", and requires its own quality criteria. The appropriateness of the methodology should centre around inclusivity so as to further knowledge on different levels. In other words, when the desired outcomes of the research project result in active participation and critical thinking by students as compared to their lack of interest prior the research, therefore, the action research engaged in significant work (Gummesson, 2000).

\subsection{Research Design}

In gathering information from my students with regard to their problem (i.e. inability to integrate information learnt into coherent manner), qualitative approach was followed. According to Leedy and Ormrod (2005), phenomenology which studies the purpose and goal of people's experiences was opted. Qualitative research design uses information that includes people's interpretations, perceptions, experiences, values and conditions. It collects information about relationships and experiences by looking for correlations and making predictions based on the data. It can generate meaningful results with a small sample group (Creswell, 2009).

\subsection{Sampling}

In this action research, convenience and purposive samplings were chosen based on the availability of participants in one of the Psychology Foundation class and for their direct involvement (i.e. purposive).

- Sample: According to Swartz et al., (2011), sample is a group of participants which represent the entire population, from which inferences can be made. Therefore, in this research study, my sample consisted of 12 males and 14 females, who voluntarily participated in the peer -assessment exercise and filling of questionnaires. The participants grouped themselves in five per group and only six members in another group.

\section{Ethical Considerations}

Ethical principles were be complied with as they serve to safeguard the dignity, rights, safety and well-being of all the participants in the research study (Marks \& Yardley, 2004). The researcher ensured that the ethical principles meet the national and international standards governing research of this nature with human participants (Leedy \& Ormrod, 2005). It is important to note that this research study was part of the module of the Postgraduate Diploma in Higher Education and Training I registered for, in 2012.

Permission for the participation in this action research was obtained from the students. Participation was voluntary and non-discriminatory.

The following ethical measures were adhered to during the research: 
- Informed consent: By informed consent, Marks and Yardley (2004) state that the participants must be told prior to the research what the experimental procedure will entail and furthermore they may cease participation in the study at any time without penalty as the study is voluntary. According to Buchanan, Miller and Wallerstein (2007), evaluators should adhere to this principle to respect the community autonomy. I therefore discussed their challenge (i.e. inability to write, formulate sentences and reason logically, which leads to poor academic performance). They showed willingness to participate.

- Confidentiality and anonymity of the participants: The information was collected by means of questionnaires to ensure confidentiality and anonymity (Creswell, 2009). The research participants' right to privacy was respected. Upon reading to them the purpose of the research, I distributed consent forms to them to acknowledge that their participation is voluntary and the information received will be for educational purpose only and their names will not be revealed.

- Protection from harm: Research participants were not exposed to undue physical or psychological harm. The researcher ensured that reasonable efforts were made to minimize the discomfort and loss of self-esteem, as suggested by Marks and Yardley (2004). There were no sensitive questions asked by the researcher.

\section{Data Collection}

Data was collected by means of open-ended questionnaires. The questionnaires were completed anonymously by participants. This enabled the participants to share their experiences freely in the form of groups of six.

\subsection{Data analysis}

To identify themes of this study, the researcher used the following steps as suggested by de Vos, Strydom, Fouche and Delport (2005): open coding, axial coding and selective coding. In open coding the data was divided into segments and then scrutinized for commonalities that reflected categories or themes. After the data was categorized it was further examined for properties, specific attributes or subcategories that characterized each category. Secondly, axial coding was done. Axial coding entails making interconnections among the categories and subcategories (Leedy and Ormrod, 2005).

\section{Discussion of Findings}

Theme1- Interaction with the lecturer

Majority of the respondents reported that when they interact with the lecturer, they perform better academically. For example, the groups responded as follows:

"Interaction with the lecturer made us to participate in any group and we are able to bring our ideas in the discussion". "By asking us questions in the first 5 minutes of our lessons, our Psychology lecturer gives us a chance to build selfconfidence and be able to study constantly even on our own"

"it is positive. It helps in our daily social lives as well as it helps us in understanding other courses not only psychology".

Drawing from the theory of involvement and persistence by Astin (1993), students develop heuristic learning and self-efficacy. According to Swartz et al ., (2011), it is clear that when students are being engaged in discussions during lectures, the principle of reinforcement through shaping results in independence and intellectual growth.

Theme 2- Gaining more knowledge

With regard to the question "How has group- discussion with other students contributed in understanding of topics?", majority of respondents reported that they gain more knowledge and acquire the skill of breaking down a topic in small units, and in the process their vocabulary improves because they debate. Furthermore, the participants reported that doing exercises in a group- form enabled them to be stimulated cognitively and to express themselves freely and with confidence. Below are some of the extracts:

"It is good because we are able to debate positively about the topics, at the end we come up with various answers". "We acquire critical reasoning skills when we are discussing topics. Our language develops in the process because of the encouragement we get from one another as group mates"

"Discussion is the best way of learning because it builds and trains us intellectually on how to express our own ideas and our own experiences". 
"It contributed well in the sense that when I discuss the work with the group I gain more knowledge."

It is clear that when there is dialogue as suggested by Northledge (2003), vicarious learning takes place and students become critical thinkers of the content. In other words, as the students gain self-confidence, their reasoning broadens. Pithers and Soden (2010) call this critical thinking. Critical thinking involves abilities to clarify, analyse and making inferences from the information learnt. This empirical finding is in line with the work by Barker, Quennerstedt and Annerstedt (2013) who emphasize on students'sociocognitive skills that when they participate jointly, through interaction their language also improves.

Theme 3- Self- efficacy versus risk factors

According Rostoskyar, Dekhty, Cupp and Anderman (2008), self-efficacy is an individual's beliefs about his/her ability to perform a particular behaviour in a given situation, mediating the relation, knowledge and skills related to performing a behaviour and his or her actual performance of the behaviour. Majority of participants reported that their academic excellence may rely on building their self-esteem, overcoming environmental stressors such as financial constraints and depression caused by poor family backgrounds. With regard to the question: "At a personal level, how can you improve your academic performance"? The responses from the participants emphasized competency, endurance and optimism in the face of adversity, as crucial in ensuring good grades in order to advance with their studies.

"We have to remain positive and never decide to quit because it would be difficult for us in future if we would be without education"

"We must apply for sponsors in order to achieve our goals. Lack of financial support contribute to our poor academic performance"

"As students, we must prioritize and build our self-esteem through aiming high despite our family backgrounds, though it is tough"

It is evident that South African students who come from impoverished families experience multiple risk factors (e.g lack of finance, stress) which could hinder them from achieving their goals. Holborn and Eddy (2011) and Letseka (2009) highlight that the scourge of poverty, HIVIAIDS, divorce and orphanhood in many black households will continue creating gaps when it comes to education and contribute towards lower graduation rates. Holland (2012) posits that when students become dropouts and consequently unemployed that will result to a lack of self-esteem and self-doubt.

Theme 4: Problem Solving

The problem identified by my students/ participants was that when they study individually, they miss a lot as compared to then they study in a group. The action taken by participants thereafter led to collaboration of exploring ways of improving their study methods. Participants agreed on studying and discussing Psychology as a group as it enabled them to freely express themselves among their peers. In evaluating the implementation of the collaboration, an individual assessment exercise was given to them a month later. In comparison to previous grades or marks obtained by students, students showed a remarkable improvement. The diagram below illustrates the steps that were taken to overcome poor academic performance of Psychology Foundation class.

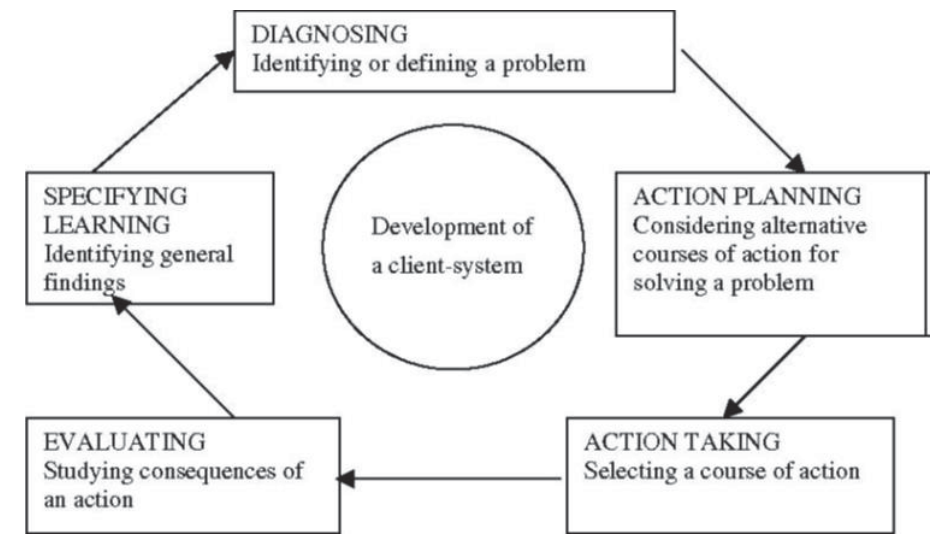

Figure 1. The cyclical process of action research (Susman \& Evered, 1978). 


\section{Recommendations}

As universities are dynamic socio- technical systems, lecturers need to have a broad view of how the system works, hence change and transformation are inevitable. There should be acquisition of new knowledge and skills for sustainability and growth. From transmission perspective, Pratt (2004) emphasizes that effective teaching should be characterized by commitment of lecturers and mastery of the learning content. When the lecturers master their modules, students' abilities to conceptualize increase and their receptivity of the content become meaningful. In case of poor academic performance, the tracking system should be in place and remediation or psychological support be provided. Finally, financially disadvantaged students should have access to student loans and competitive scholarship in order to complete their studies, although there is a major crises for developing country governments to accommodate all students in dire need of funding (World Bank, 1994).

\section{References}

Antonio, A. L., Astin, H. S., \& Cress, C. M. (2000). Community service in higher education: A look at the nation's faculty. The Review of Higher Education, 23(4), 373-397.

Astin, A. W. (1993). What matters in college? Four critical years revisited. San Francisco: Jossey- Bass.

Barker, D., Quennerstedt, M., \& Annerstedt, C. (2013). Inter-student interactions and student learning in health and physical education: a post-Vygotskian analysis. Physical Education and Sport Pedagogy, (ahead-of-print), 1-18.

Bee, D., \& Boyd, D. (2003). Life-span development. Study edition. (3rd ed.). Boston: Allyn \& Bacon.

Boughey, C. (2000). Multiple metaphors in an understanding of academic literacy. Teachers and Teaching: theory and practice, 6(3), 279-290.

Bozalek, V., \& Biersteker, L. (2010). Exploring power and privilege using participatory learning and action techniques. Social Work Education, 29(5), 551-572.

Buchanan, D. R., Miller, F. G., \& Wallerstein, N. (2007). Ethical issues in community-based participatory research: balancing rigorous research with community participation in community intervention studies. Progress in Community Health Partnerships:

Research, Education, and Action, 1(2), 153-160.

Creswell J.W (2009), Research design, qualitative, quantitative \& mixed methods approaches (3 ${ }^{\text {rd }}$ edition). London: Sage publications Inc.

Department of Education (DoE). (2002). Draft guidelines for the implementation of inclusive education (Second draft). Pretoria : Government Printer

De Jager, R. (2011). Latest changes in the Technology Education curriculum in South Africa. In Conference Proceedings of PATT 25: CRIPT, Vol. 8: 144-150.

De Vos A.S., Strydom H., Fouche, C.B., \& Delport C.S.L. (2005). Research at Grass roots: For Social Science and Human Service professions. ( $3^{\text {rd }}$ ed.). Pretoria: Van Schaik Publishers.

Field, J., \& Leicester, M. (Eds.). (2003). Lifelong learning: Education across the lifespan. Psychology Press.

Gummesson, E. (2000). Qualitative Methods in Management. (2nd rev. ed.). Thousand Oaks, CA: Sage.

Holborn, L., \& Eddy, G. (2011). First steps to healing the South African family. Johannesburg: South African Institute of Race Relations.

Holland, K. (2012). Effects of Unemployment on Health and Mental Health Based on Gender. Master of Social Work Clinical Research Papers. Paper 38. [Retrieved 07 July2014, from http://sophia.stkate.edu/cgi/viewcontent.cgi?article=1038\&context=msw_papers]

Kreber, C. (2004). An analysis of two models of reflection and their implications for educational development. International Journal for Academic Development, 9(1), 29-49.

Leedy , P.D. \& Ormrod, J.E. (2005). Practical Research. Planning and Design.(8th Edition). Upper Saddle River, New Jersey: Pearson Prentice Hall.

Letseka, M. (2009). University drop-out and researching (lifelong) learning and work. In L. Copper \& S. Walters (Ed.). Learning/work: Turning work and lifelong learning inside out. HSRC Press: Cape Town, South Africa

Letseka, M., \& Breier, M. (2008). Student poverty in higher education: the impact of higher education dropout on poverty.

Nicholas, L. (2008). Introduction to Psychology. (2nd edition). Cape Town : UCT Press.

Marks, D. F., \& Yardley, L. (Eds.). (2004). Research methods for clinical and health psychology. Thousands Oak, California: Sage.

Mudau, S.P. (2004). The attitudes of foundation phase teachers to the inclusive of learners who experience barriers to learning in the education system. Pretoria : University of South Africa.

Nel, N., \& Müller, H. (2010). The impact of teachers' limited English proficiency on English second language learners in South African schools. South African Journal of Education, 30(4), 635-650.

Nonyane, J., \& Mlitwa, N. (2008). ICT access and use in rural schools in South Africa: A case study in Mpumalanga Province. Section 1: IS, ICT \& E-commerce, E-health, E-learning, 1:94-104.

Northledge, A. (2003). Rethinking teaching in the context of diversity. Teaching in Higher Education, 8(1): 17-32.

Pithers, R. T., \& Soden, R. (2000). Critical thinking in education: A review. Educational Research, 42(3), 237-249.

Pratt, D.D., \& Associates. (1998). Five Perspectives on Teaching in Adult and HigherEducation. Malabar, FL: Krieger Publishing.

Rostosky, S.S., Dekhtyar, O., Cupp, P.K. \&Anderman, E.M. (2008). Sexual Self -Concept and Sexual Self efficacy in Adolescents: A 
possible clue to promoting sexual health. Journal of Sex Research, 45: 3, 277-286.

Scott, I. (2009). First-year experience as terrain of failure or platform for development? Critical choices for higher education. Focus on first-year success: Perspectives emerging from South Africa and beyond, 17-35.

Susman, G. I., \& Evered, R. D. (1978). An assessment of the scientific merits of action research. Administrative science quarterly, 582603.

Swartz, L., de la Rey, C., Duncan, N., Townsend, L. \& O’Neil. (2011). Psychology. An introduction. (2nd ed.). Cape-Town: Oxford University Press.

Trigwell, K., Martin, E., Benjamin, J., \& Prosser, M. (2000). Scholarship of teaching: A model. Higher education research and development, 19(2), 155-168.

Walker, M. (1993). Developing the theory and practice of action research: a South African case. Educational Action Research, 1(1), 95109.

Wilkerson, L., \& Irby, D. M. (1998). Strategies for improving teaching practices: a comprehensive approach to faculty development. Academic Medicine, 73(4), 387-96.

World Bank. (1994). Higher Education: The lessons of experience. Washington, DC: World Bank. 